\title{
INNOVATIVE TEACHING PROJECT: PRICES AND COSTS OF DRUGS USED TO FIGHT AGAINST COVID-19
}

\author{
Cristina Vilaplana-Prieto \\ Prof. Dr., University of Murcia, SPAIN, cvilaplana@um.es
}

\begin{abstract}
As the Sars-CoV2 pandemic continues to grow, researchers around the world are urgently seeking new treatments to prevent infection, cure those infected, or lessen the severity of the disease. Although there are several recently approved vaccines, clinical trials are underway to "re-use" drugs normally indicated for other diseases. This teaching experience studies the market for 8 pharmaceutical products used to fight the pandemic (remdesivir, favipiravir, lopinavir/ritonavir, chloroquine, hydroxychloroquine, sofosbuvir, pyrfenidone and tocilizumab) in 13 countries (Bangladesh, Brazil, China, Egypt, France, India, Malaysia, Pakistan, South Africa, Sweden, Turkey, United Kingdom and United States). Through the analysis of prices and costs, we reflect on the difficulty of access to treatment according to the country. The objective is to deepen knowledge of the pharmaceutical market: (i) to demonstrate in a tangible way the differences between production costs and final prices of medicines, (ii) to perceive the difficulty of access to certain treatments depending on the country, (iii) to reflect on what initiatives should be implemented in an international emergency context such as the one we are experiencing.
\end{abstract}

Keywords: patents, COVID-19, pharmaceutical products, mark-up, costs

\section{INTRODUCTION}

As the Sars-CoV2 pandemic continues to grow, researchers around the world are urgently seeking new treatments to prevent infection, cure those infected, or lessen the severity of the disease. As of 9 January 2021, 87.5 million cases have been confirmed and 1.9 million people have died. Although there are several recently approved vaccines, clinical trials are underway to "re-use" drugs normally indicated for other diseases (Li and LeClercq, 2020). The shorter development time and reduced costs of using existing compounds are particularly advantageous compared to the discovery of new drugs in a pandemic situation, where time is of the essence.

Antiviral drugs include the nucleotide analogue remdesivir, which was previously used experimentally but without success against Ebola (Siegal et al, 2017), favipiravir, used to treat influenza (Hayden and Shindo, 2019), the HIV protease inhibitor lopinavir/ritonavir (Cao et al., 2020), the antimalarials chloroquine and hydroxychloroquine (Yao et al., 2020), and the direct-acting antivirals sofosbuvir and daclatasvir (IRCT, 2020). In addition, treatments to improve lung function and reduce inflammation, such as pyrfenidone (WIPO, 2017) and tocilizumab (ClinicalTrials.gov, 2020), are being evaluated in clinical trials.

Most of the clinical trials reported so far are small pilot studies, often non-randomised, making interpretation of the current evidence difficult. If the results of these new trials are favourable, there is a possibility of rapidly increasing the production of the most promising drugs. The safety profiles of these drugs have already been established from clinical trials for other diseases, so they could be rapidly deployed to treat HIV-19 before vaccines become available.

Low- and middle-income countries will need access to these treatments at minimum prices to ensure that all 
who need them can be treated. Even in high-income countries, the disease burden could be so great that access to medicines at minimal cost may also be necessary. The HIV epidemic has been controlled by mass treatment with antiretroviral drugs around the world at very low unit cost. Large donor organizations, such as the Global Fund to Fight Immunodeficiency, Tuberculosis and Malaria and the United States President's Emergency Plan for Immunodeficiency Relief, are ordering drugs to treat more than 20 million people with HIV, at prices close to the cost of production (PEPFAR, 2019; The Global Fund, 2020). This system enables low- and middle-income countries to access high-quality drugs at affordable prices.

This educational project is designed for students in Economics, Business Administration, Political Science and Sociology. The objective is to deepen knowledge of the pharmaceutical market: (i) to demonstrate in a tangible way the differences between production costs and final prices of medicines, (ii) to perceive the difficulty of access to certain treatments depending on the country, (iii) to reflect on what initiatives should be implemented in an international emergency context such as the one we are experiencing. This will be done by consulting statistical bases and reading support documents on the structure of the pharmaceutical market. It is best to carry out this practice in small groups and then share it in order to favour "withing groups" and "between groups" interactions.

\section{METODOLOGY}

The execution of this project involves different phases. Firstly, the estimation of the cost of pharmaceutical products. Secondly, the search for information on the retail price of pharmaceutical products. Thirdly, an activity of reading and reflection on the pharmaceutical market and its specificities. Fourthly, carrying out a series of mathematical exercises and analysing the results obtained. Finally, the development of proposals to improve access to medicines in the context of a health emergency.

\subsection{Preparation of Price and Cost Information}

The minimum production costs of medicines can be estimated by calculating the cost of active pharmaceutical ingredients, which is combined with the costs of excipients, formulation, packaging and a profit margin to estimate the price of the 'finished product', i.e. the ready-to-use medicine (Hill et al., 2018). Table 1 shows, for each drug, the duration of treatment and the number of doses to be administered each day, the daily cost of treatment and the total cost.

Table 1. Characteristics of each drug. Daily cost and total cost

\begin{tabular}{|c|c|c|c|c|}
\hline & $\begin{array}{c}\text { Length of } \\
\text { the } \\
\text { treament }\end{array}$ & Daily doses & $\begin{array}{c}\text { Total } \\
\text { treatment } \\
\text { cost }(\$)\end{array}$ & $\begin{array}{c}\text { Daily } \\
\text { cost }(\$)\end{array}$ \\
\hline Remdesivir & 10 days & $\begin{array}{c}2 \text { the 1st day; } \\
\text { other days }\end{array}$ & 9 & 0,93 \\
\hline Favipiravir & 14 days & 2 per day & 20 & 1,45 \\
\hline Lopinavir & 14 days & 2 per day & 4 & 0,28 \\
\hline Hidroxcicloroquina & 14 days & 1 per day & 1 & 0,08 \\
\hline Cloroquina & 14 days & 1 per day & 0,3 & 0,02 \\
\hline Azitromicina & 14 days & 1 per day & 1,4 & 0,2 \\
\hline Sofosvubir & 14 days & 1 per day & 5 & 0,39 \\
\hline Pirfenidone & 28 days & 3 per day & 31 & 1,09 \\
\hline Tocilizumab & - & 2 & 177,5 & 355 \\
\hline
\end{tabular}

Source: Own work using data from Hill et al. (2020). For Tocilizumab the table has been completed using information from Table 1, Cost-Comparison Table for Biologic Disease-Modifying Drugs for Rheumatoid Arthritis - Tocilizumab (Actemra) - NCBI Bookshelf (nih.gov) 
Price information was obtained through published lists for each medicine in a number of countries (Bangladesh, Brazil, China, Egypt, France, India, Malaysia, Pakistan, South Africa, Sweden, Turkey, United Kingdom and United States) to provide a representative sample of prices in countries with different levels of economic development, although all the medicines analysed in this study are available in the selected countries. Where more than one price was available for the same medicine, the lowest price was chosen. Table 2 shows the price of full treatment for each drug and country.

Table 2. Price for complete COVID-19 treatment $(\$)$

\begin{tabular}{|l|r|r|r|r|r|r|r|r|r|}
\hline & $\begin{array}{c}\text { Remde } \\
- \\
\text { sivir }\end{array}$ & $\begin{array}{r}\text { Favipi- } \\
\text { ravir }\end{array}$ & $\begin{array}{c}\text { Lopinav } \\
\text { ir }\end{array}$ & $\begin{array}{c}\text { Hidroxc } \\
\text { i- } \\
\text { cloroqui } \\
\text { na }\end{array}$ & $\begin{array}{c}\text { Cloro- } \\
\text { quina }\end{array}$ & $\begin{array}{c}\text { Azitro- } \\
\text { micina }\end{array}$ & $\begin{array}{c}\text { Sofosv } \\
\text { ubir }\end{array}$ & $\begin{array}{c}\text { Pirfeni- } \\
\text { done }\end{array}$ & $\begin{array}{c}\text { Tocilizu } \\
\text {-mab }\end{array}$ \\
\hline $\begin{array}{l}\text { Banglades } \\
\text { h }\end{array}$ & 600 & - & - & 3 & 0,2 & 5 & 168 & 124 & 690 \\
\hline Brazil & 600 & - & - & - & - & 19 & 4289 & - & - \\
\hline China & 600 & 231 & 17 & 19 & 5 & 7 & - & 1379 & 1.950 \\
\hline Egypt & 600 & - & - & - & - & - & - & - & 606 \\
\hline $\begin{array}{l}\text { United } \\
\text { States }\end{array}$ & 3.120 & - & 503 & 18 & 93 & 63 & 18610 & 9.606 & 3.383 \\
\hline France & 2.340 & - & 97 & 5 & - & 44 & - & 2.344 & - \\
\hline India & 600 & 112,8 & 40 & 2 & 1 & 5 & 7 & 100 & 806 \\
\hline Malasya & 600 & - & - & 7 & 2 & 11 & - & - & - \\
\hline Pakistan & 600 & - & - & - & - & - & 6 & - & 510 \\
\hline United \\
Kingdom
\end{tabular}

Source: Hill et al. (2020). For remdesivir and favipiravir, information has been completed using Remdesivir developed country price announced | Medicines Law \& Policy (medicineslawandpolicy.org) y India's Glenmark cuts price of COVID-19 drug favipiravir version to $\$ 1$ per tablet $\mid$ Reuters. Price for treatment with remdesivir was $600 \$$ in developing countries, $2.340 \$$ in developed countries and 3.120 in United States.

\section{2 . Content of the Practice}

The practice begins with the reading of two documents: "Patents, price regulation and innovation in the pharmaceutical industry" and "Drug price differentials across different retail market settings", both available on the internet (see references). After this reading, the following introductory questions are posed:

1. What special characteristics differentiate medicines from other goods?

2. What type of market do you consider to be the pharmaceutical market?

3. Does it share characteristics with a market of perfect competition? Given your answer to this question, do you consider that there may be a market failure in the pharmaceutical market?

4. What are the advantages and disadvantages of pharmaceutical patents? 
5. Do you consider that the knowledge on which new pharmaceutical products are based is a public good?

6. With the information in tables 1 and 2, a series of exercises are proposed.

2.2.1 Exercise 1: Calculate the Average Price and Standard Deviation for Each Drug. What Do You Notice?

Tabla 2. Mean and standard deviation for each complete treatment for COVID-19

\begin{tabular}{|c|c|c|c|c|c|c|c|c|c|}
\hline & $\begin{array}{c}\text { Remde } \\
- \\
\text { sivir }\end{array}$ & $\begin{array}{c}\text { Favipi- } \\
\text { ravir }\end{array}$ & $\begin{array}{c}\text { Lopinavi } \\
\mathrm{r}\end{array}$ & $\begin{array}{c}\text { Hidroxci } \\
- \\
\text { cloroqui } \\
\text { na }\end{array}$ & $\begin{array}{c}\text { Cloro- } \\
\text { quina }\end{array}$ & $\begin{array}{c}\text { Azitro- } \\
\text { micina }\end{array}$ & $\begin{array}{c}\text { Sofosvu } \\
\text { bir }\end{array}$ & $\begin{array}{c}\text { Pirfenid } \\
\text { one }\end{array}$ & $\begin{array}{c}\text { Tocilizu } \\
\text { mab }\end{array}$ \\
\hline Mean & $\begin{array}{c}1.195,3 \\
8\end{array}$ & 171,90 & 142,13 & 7,11 & 14,78 & 21,60 & $\begin{array}{c}5.152,0 \\
0\end{array}$ & $\begin{array}{c}2.477,6 \\
7\end{array}$ & $\begin{array}{c}1.119,4 \\
4\end{array}$ \\
\hline $\begin{array}{c}\text { Standar } \\
\mathrm{d} \\
\text { deviatio } \\
\mathrm{n}\end{array}$ & 949,78 & 68,92 & 140,72 & 6,40 & 25,35 & 19,36 & $8.420,5$ & $\begin{array}{c}2.602,4 \\
9\end{array}$ & 947,38 \\
\hline & & & & & & & & \\
\hline
\end{tabular}

Source: Own work

- There are medicines with a very low average price (hydroxychloroquine, chloroquine and azithromycin), but there are also very expensive ones (remdesivir, pirfenidone, sofosvubir).

- Within a single drug, there is also wide variability between countries (perfenidone, tociluzumab).

2.2.2 Exercise 2: Calculate the Mark-up Ratio for Each Drug and Each Country, Taking into Account the Price and Cost Data for the Entire Treatment. Also Calculate the Mean and Standard Deviation of the Mark-up Ratio for Each Drug:

$$
\text { Mark }- \text { up ratio or Profit ratio }=\frac{\text { Price }- \text { Marginal cost }}{\text { Marginal cost }}
$$

Table 4. Mark-up rate for complete COVID-19 treatment

\begin{tabular}{|l|r|r|r|r|r|r|r|r|r|}
\hline & $\begin{array}{r}\text { Remde- } \\
\text { sivir }\end{array}$ & $\begin{array}{r}\text { Favipi- } \\
\text { ravir }\end{array}$ & $\begin{array}{r}\text { Lopinav } \\
\text { ir }\end{array}$ & $\begin{array}{r}\text { Hidroxc } \\
\text { i- } \\
\text { cloroqui } \\
\text { na }\end{array}$ & $\begin{array}{r}\text { Cloro- } \\
\text { quina }\end{array}$ & $\begin{array}{r}\text { Azitro- } \\
\text { micina }\end{array}$ & $\begin{array}{r}\text { Sofosv } \\
\text { ubir }\end{array}$ & $\begin{array}{r}\text { Pirfenid } \\
\text { one }\end{array}$ & $\begin{array}{r}\text { Tocilizu } \\
\text { mab }\end{array}$ \\
\hline $\begin{array}{l}\text { Banglad } \\
\text { esh }\end{array}$ & 65,67 & - & - & 2,00 & $-0,33$ & 2,57 & 32,60 & 3,00 & 0,94 \\
\hline Brazil & 65,67 & - & - & - & - & 12,57 & 856,80 & - & - \\
\hline China & 65,67 & 10,55 & 3,25 & 18,00 & 15,67 & 4,00 & - & 43,48 & 4,49 \\
\hline Egypt & 65,67 & - & - & - & - & - & - & - & 0,71 \\
\hline United & 345,67 & - & 124,75 & 17,00 & 309,00 & 44,00 & 0 & 308,87 & 8,53 \\
\hline States & 259,00 & - & 23,25 & 4,00 & - & 30,43 & - & 74,61 & - \\
\hline France & 65,67 & 4,64 & 9,00 & 1,00 & 2,33 & 2,57 & 0,40 & 2,23 & 1,27 \\
\hline
\end{tabular}


Proceedings of SOCIOINT 2021 8th International Conference on Education and Education of Social Sciences 14-15 June, 2021

\begin{tabular}{|l|r|r|r|r|r|r|r|r|r|}
\hline Malasya & 65,67 & - & - & 6,00 & 5,67 & 6,86 & - & - & - \\
\hline $\begin{array}{l}\text { Pakista } \\
\mathrm{n}\end{array}$ & 65,67 & - & - & - & - & - & 0,20 & - & 0,44 \\
\hline $\begin{array}{l}\text { United } \\
\text { Kingdo } \\
\mathrm{m}\end{array}$ & 259,00 & - & 35,00 & 3,00 & 25,67 & 6,86 & $\begin{array}{r}1.565,4 \\
0\end{array}$ & 81,61 & 1,57 \\
\hline $\begin{array}{l}\text { South } \\
\text { Africa }\end{array}$ & 65,67 & - & 2,75 & - & 15,67 & 24,00 & - & 79,32 & 0,59 \\
\hline Sweden & 259,00 & - & 42,00 & 2,00 & 12,33 & 10,43 & - & 69,84 & - \\
\hline Turkey & 65,67 & - & 36,25 & 2,00 & - & - & - & 47,35 & 0,83 \\
\hline $\begin{array}{l}\text { Mean } \\
\text { Standar }\end{array}$ & 131,82 & 7,60 & 34,53 & 6,11 & 48,25 & 14,43 & $\begin{array}{r}1.029,4 \\
0\end{array}$ \\
\hline \begin{tabular}{l} 
deviatio \\
\hline
\end{tabular} & 105,53 & 3,10 & 34,92 & 6,15 & 84,34 & 13,62 & $\begin{array}{r}1.083,8 \\
6\end{array}$ & 88,92 & 2,15 \\
\hline
\end{tabular}

Source: Own work

- The lowest profit margin corresponds to tocilizumab, favipiravir, hydroxychloroquine and azithromycin.

- The highest profit margin corresponds to sofosvubir.

2.2.3 Exercise 3: Find the GDP per Capita for Each Country (e.g. World Bank statistics) and Compare the Cost of the Full Treatment for VOC-19 with the GDP per Capita of Each Country. Comment on the Results.

Table 5. Percentage of complete treatment price with respect to per capita GDP.

\begin{tabular}{|l|c|c|c|c|c|c|c|c|c|c|}
\hline & $\begin{array}{c}\text { GDP } \\
\text { (per } \\
\text { capita } \\
\$ \text { ( }\end{array}$ & $\begin{array}{c}\text { Remd } \\
\text { e- } \\
\text { sivir }\end{array}$ & $\begin{array}{c}\text { Favip } \\
\text { i- } \\
\text { ravir }\end{array}$ & $\begin{array}{c}\text { Lopina } \\
\text { vir }\end{array}$ & $\begin{array}{c}\text { Cloroqui } \\
\text { na }\end{array}$ & $\begin{array}{c}\text { quin } \\
\text { a }\end{array}$ & $\begin{array}{c}\text { micin } \\
\text { a }\end{array}$ & $\begin{array}{c}\text { Sofosvu } \\
\text { bir }\end{array}$ & $\begin{array}{c}\text { Pirfenido } \\
\text { ne }\end{array}$ & $\begin{array}{c}\text { Tociliz } \\
\text { umab }\end{array}$ \\
\hline $\begin{array}{l}\text { Banglade } \\
\text { sh }\end{array}$ & $\begin{array}{c}1.855, \\
7\end{array}$ & 32,33 & - & - & 0,16 & 0,01 & 0,27 & 9,05 & 6,68 & 37,18 \\
\hline Brazil & $\begin{array}{c}8.717 \\
2\end{array}$ & 6,88 & - & - & - & - & 0,22 & 49,20 & - & - \\
\hline China & $\begin{array}{c}10.261 \\
, 7\end{array}$ & 5,85 & 2,25 & 0,17 & 0,19 & 0,05 & 0,07 & - & 13,44 & 19,00 \\
\hline Egypt & $\begin{array}{c}3.019 \\
2\end{array}$ & 19,87 & - & - & - & - & - & - & - & 20,07 \\
\hline United & $\begin{array}{c}65.297 \\
\text { States }\end{array}$ & 4,78 & - & 0,77 & 0,03 & 0,14 & 0,10 & 28,50 & 14,71 & 5,18 \\
\hline France & $\begin{array}{c}40.493 \\
, 9\end{array}$ & 5,78 & - & 0,24 & 0,01 & - & 0,11 & - & 5,79 & - \\
\hline
\end{tabular}


Proceedings of SOCIOINT 2021 8th International Conference on Education and Education of Social Sciences 14-15 June, 2021

\begin{tabular}{|l|c|c|c|c|c|c|c|c|c|c|}
\hline India & $\begin{array}{c}2.099 \\
6\end{array}$ & 28,58 & 5,37 & 1,91 & 0,10 & 0,05 & 0,24 & 0,33 & 4,76 & 38,39 \\
\hline Malasya & $\begin{array}{c}11.414 \\
, 2\end{array}$ & 5,26 & - & - & 0,06 & 0,02 & 0,10 & - & - & - \\
\hline Pakistan & $\begin{array}{c}1.284 \\
7\end{array}$ & 46,70 & - & - & - & - & - & 0,47 & - & 39,70 \\
\hline $\begin{array}{l}\text { United } \\
\text { Kingdom }\end{array}$ & $\begin{array}{c}42.330 \\
, 1\end{array}$ & 5,53 & - & 0,34 & 0,01 & 0,02 & 0,03 & 18,50 & 6,05 & 2,16 \\
\hline $\begin{array}{l}\text { South } \\
\text { Africa }\end{array}$ & $\begin{array}{c}6.001 \\
4\end{array}$ & 10,00 & - & 0,25 & - & 0,08 & 0,58 & - & 41,49 & 9,43 \\
\hline Sweden & $\begin{array}{c}51.615 \\
, 0\end{array}$ & 4,53 & - & 0,33 & 0,01 & 0,01 & 0,03 & - & 4,25 & - \\
\hline Turkey & $\begin{array}{c}9.126 \\
6\end{array}$ & 6,57 & - & 1,63 & 0,03 & - & - & - & 16,42 & 7,12 \\
\hline
\end{tabular}

Source: Own work using data from GDP per capita (current US\$) | Data (worldbank.org)

- Treatment with some drugs is relatively expensive compared to the country's GDPpc: remdesivir accounts for $28 \%$ in India, $32 \%$ of GDPpc in Bangladesh, $46 \%$ in Pakistan; pirfenidone accounts for $16 \%$ in Turkey and $41 \%$ in South Africa.

2.2.4 Exercise 4: Look at public health expenditure per capita (e.g. World Bank statistics) and compare it to the cost of full treatment for VOCs-19. Comment on the results.

Table 6. Percentage of complete treatment price with respect to per capita health expenditure.

\begin{tabular}{|c|c|c|c|c|c|c|c|c|c|c|}
\hline & $\begin{array}{l}\text { Public } \\
\text { health } \\
\text { expendit } \\
\text { ure (per } \\
\text { capita, \$) }\end{array}$ & $\begin{array}{l}\text { Remd } \\
\text { e- } \\
\text { sivir }\end{array}$ & $\begin{array}{l}\text { Favi } \\
\text { pi- } \\
\text { ravir }\end{array}$ & $\begin{array}{l}\text { Lopina } \\
\text { vir }\end{array}$ & $\begin{array}{l}\text { Hidroxci } \\
- \\
\text { cloroqui } \\
\text { na }\end{array}$ & $\begin{array}{c}\text { Clor } \\
\text { o- } \\
\text { quin } \\
\text { a }\end{array}$ & $\begin{array}{c}\text { Azitr } \\
\text { o- } \\
\text { mici } \\
\text { na }\end{array}$ & $\begin{array}{c}\text { Sofosvu } \\
\text { bir }\end{array}$ & $\begin{array}{c}\text { Pirfenido } \\
\text { ne }\end{array}$ & $\begin{array}{l}\text { Tociliz } \\
\text { umab }\end{array}$ \\
\hline $\begin{array}{l}\text { Banglad } \\
\text { esh }\end{array}$ & 7,12 & $\begin{array}{r}8.426 \\
97\end{array}$ & - & - & 42,13 & 2,81 & $\begin{array}{r}70,2 \\
2\end{array}$ & $\begin{array}{r}2.359,5 \\
5\end{array}$ & $1.741,57$ & $\begin{array}{r}9.691 \\
01\end{array}$ \\
\hline Brazil & 353,54 & 169,71 & - & - & - & & 5,37 & $\begin{array}{r}1.213,1 \\
6\end{array}$ & & \\
\hline China & 282,68 & 212,25 & $\begin{array}{r}81,7 \\
2\end{array}$ & 6,01 & 6,72 & 1,77 & 2,48 & - & 487,83 & $\begin{array}{r}689,8 \\
3\end{array}$ \\
\hline Egypt & 36,07 & $\begin{array}{r}1.663 \\
43\end{array}$ & - & - & - & - & & - & - & $\begin{array}{r}1.680 \\
07\end{array}$ \\
\hline $\begin{array}{l}\text { United } \\
\text { States }\end{array}$ & $5.355,79$ & 58,25 & - & 9,39 & 0,34 & 1,74 & 1,18 & 347,47 & 179,36 & 63,17 \\
\hline France & $3.441,17$ & 68,00 & - & 2,82 & 0,15 & - & 1,28 & - & 68,12 & - \\
\hline India & 19,63 & $\begin{array}{r}3.056 \\
55\end{array}$ & $\begin{array}{r}574, \\
63\end{array}$ & 203,77 & 10,19 & 5,09 & $\begin{array}{r}25,4 \\
7\end{array}$ & 35,66 & 509,42 & $\begin{array}{r}4.105 \\
96\end{array}$ \\
\hline Malasy & 218,65 & 274,41 & & & 3,20 & 0,91 & 5,03 & & & \\
\hline
\end{tabular}




\begin{tabular}{|c|c|c|c|c|c|c|c|c|c|c|}
\hline$a$ & & & & & & & & & & \\
\hline $\begin{array}{l}\text { Pakista } \\
\mathrm{n}\end{array}$ & 15,24 & $\begin{array}{r}3.937 \\
01\end{array}$ & - & - & - & - & - & 39,37 & - & $\begin{array}{r}3.346 \\
46\end{array}$ \\
\hline $\begin{array}{l}\text { United } \\
\text { Kingdo } \\
\mathrm{m}\end{array}$ & $3.392,09$ & 68,98 & - & 4,25 & 0,12 & 0,24 & 0,32 & 230,89 & 75,50 & 26,95 \\
\hline $\begin{array}{l}\text { South } \\
\text { Africa }\end{array}$ & 284,28 & 211,06 & - & 5,28 & - & 1,76 & $\begin{array}{r}12,3 \\
1\end{array}$ & - & 875,90 & $\begin{array}{r}199,1 \\
0\end{array}$ \\
\hline Sweden & $5.089,96$ & 45,97 & - & 3,38 & 0,06 & 0,08 & 0,31 & - & 43,14 & - \\
\hline Turkey & 301,69 & 198,88 & - & 49,39 & 0,99 & - & - & 0,00 & 496,87 & $\begin{array}{r}215,4 \\
5\end{array}$ \\
\hline
\end{tabular}

Source: own work using data from Domestic general government health expenditure per capita (current US\$) Data (worldbank.org)

- The unaffordability of some of the treatments becomes even more apparent when comparing their price with public health expenditure. In India, the cheapest treatment is 5 times the public health expenditure in per capita terms. In Sweden, some treatments account for a tiny percentage of public health expenditure (hydroxychloroquine, chloroquine, azithromycin), but others account for more than $40 \%$ of public expenditure per capita (remdesivir, pirfenidone).

- Few drugs are marketed in some countries, which means that there are very few options to choose from. In Pakistan, the cost of treatment ranges from 39 to 3,000\%, in Brazil it ranges from 5 to $1,200 \%$.

- The differences between tables 5 and 6 highlight that GDP per capita is not an "ideal" indicator of economic well-being. In countries with low GDP per capita, public expenditure on health is even lower and this may make it impossible for the public health system to purchase medicines to combat the coronavirus.

\subsubsection{Exercise 5: Reflect on the Above Results and Suggest Some Measures that Could improve Affordability and Access to Treatment}

- This analysis shows that medicines to treat COViD-19 could be manufactured at very low prices. If promising results from key clinical trials emerge, there is a possibility to increase production of generics and provide treatment to millions of people at very low unit prices.

- Large orders are needed to encourage generic companies to manufacture medicines at low prices, as is the case for AIDS, malaria and TB medicines.

- Other mechanisms are in place to optimise drug manufacturing. With joint procurement, a number of countries can order medicines together, to take advantage of economies of scale. There can be volumeprice guarantees to purchase large quantities of medicines at fixed prices for a certain number of years.

- Prequalification of major companies by the WHO can be recognized by any country as an indicator of the quality of the medicine, including adherence to good manufacturing practices and the stability or viability of the medicine over its stated shelf life, along with the bioequivalence of generic to branded versions.

- There should be no intellectual property barriers preventing the mass production of these treatments worldwide. We need open 'technology transfer' so that the methods used to manufacture key medicines can be shared with any country that decides to produce them locally.

\section{DISCUSSION}

Students should reflect on the particularities of the pharmaceutical market. The price of a medicine can be high for two reasons. Firstly, because the cost of the active ingredients used is high. Secondly, because, due to a situation of lack of competition, the market power situation is exploited to set a high price.

Moreover, unlike in other markets where, as the number of competitors increases, the price tends to decrease (computers, mobile phones, etc.), this is not necessarily the case in the pharmaceutical market, because companies tend to include the costs of all "wasted drugs" in the price of "successful drugs". 
The comparison of prices and costs in the tables above shows that there are treatments that, if effective in combating COVID-19, could be moderately expensive (less than $\$ 30$ for a standard course of treatment). However, in many cases, the differences between prices and costs are stratospheric, which may jeopardise the accessibility of these treatments for many countries.

\section{CONCLUSION AND RECOMMENDATIONS}

This teaching experience has been very satisfactory, both from the point of view of the students' involvement and work, as well as their own assessment of the subject studied. In the first place, they have valued very positively the relevance of the project. Secondly, it has helped them to use international statistical portals that they had never used before. Thirdly, it has helped them to reflect on the difference between prices and costs, and how this difference translates into the profit margin.

Fourthly, they have carried out an in-depth reflection on the existing disparities in access to medicines. In this situation, they considered, by an overwhelming majority, that although patents aim to promote knowledge by creating a monopoly around the product or innovation developed, in the particular case of the COVID-19 pandemic, health should be prioritised, and therefore, there should be a free transfer of technology, not only at the level of medicines developed, but of all the trials carried out. It is essential that generic medicines are accessible to all people, because the health of some is good for the health of all (positive externality).

\section{REFERENCE LIST}

Cao, B., Wang, Y., Wen, D. (2020). A trial of lopinavir-ritonavir in adults hospitalized with severe Covid-19. New England Journal of Medicine, 382, 1787-1799.

ClinicalTrials.gov (2020). Tocilizumab in COVID-19 Pneumonia (TOCIVID-19). NCT04317092. US National Library of Medicine. Available at: Tocilizumab in COVID-19 Pneumonia (TOCIVID-19) - Full Text View - ClinicalTrials.gov

Godwin, S., Varatharajan, D. (2006). Drug price differentials across different retail market settings. Health Administrator, 19, 41-47.

Hayden, F., Shindo, N. (2019). Influenza virus polymerase inhibitors in clinical development. Current Opinion in Infectious Diseases, 32 (2),176-186.

Hill, A., Barber, M., Gotham, D. (2018). Estimated costs of production and potential prices for the WHO Essential Medicines List. BMJ Global Health, 3(1), e000571.

Hill, A., Wang, J., Levi, J., Heath, K., Fortunak, J. (2020). Minimum costs to manufacture new treatmetns for COVID-19. Journal of Virus Erradication, 6(2), 61-69.

Iran Registry of Clinical Trials. Registration Number: IRCT20200128046294N2. Available at: IRCT |A prospective randomized controlled trial comparing Sovodak (Sofosbuvir plus Daclatasvir) in participants with moderate to severe Coronavirus disease (COVID-19) compared to standard of care treatment

IRCT (2020). A Prospective Randomized Controlled Clinical Trial Comparing the Therapeutic Efficacy of Sovodak (Sofosbuvir/Daclatasvir) with Standard Care in Patients with Moderate to Severe Coronavirus (COVID-19) Virus (2020)

Li, G., De Clercq, E. (2020). Therapeutic options for the 2019 novel coronavirus (2019-nCoV). Nature Reviews Drug Discovery, 19 (3), 149-150.

Ortún, V. (2004). Patentes, regulación de precios e innovación en la industria farmacéutica. Cuadernos Económicos de ICE, 67, 191-2008.

PEPFAR (2019). The United States President's Emergency Plan for AIDS Relief. 2019 Annual Report to Congress 2019. Available at: PEPFAR 2019 Annual Report to Congress (state.gov)

Siegal, D.,Hui, H. , Doerffler, E. , et al. (2017). Discovery and synthesis of a phosphoramidate prodrug of a pyrrolo[2,1-f][triazine-4-amino] adenine C-nucleoside (GS-5374) for the treatment of Ebola and emerging viruses. Journal of Medicinal Chemestry 60 (5), 1648-1661. 
The Global Fund (2020). Mitigating the impact of COVID-19 on countries affected by HIV, tuberculosis and malaria. Available at: covid19 mitigatingimpact report en.pdf (theglobalfund.org)

WIPO (2017). An Improved Process for the Preparation of Pirfenidone. WO2017/122139. World Intellectual Property Office. Available at: WO2017122139A1 - An improved process for the preparation of pirfenidone - Google Patents

Yao, X., F. Ye, Zhang, M. (2020). In vitro antiviral activity and projection of optimized dosing design of hydroxychloroquine for the treatment of severe acute respiratory syndrome coronavirus 2 (SARSCoV-2). Clinical Infectious Diseases, 71(15), 732-739. 